Trinity College

Trinity College Digital Repository

Faculty Scholarship

Summer 2005

Stendhal and the Trials of Ambition in Postrevolutionary France

Kathleen Kete

Trinity College, kathleen.kete@trincoll.edu

Follow this and additional works at: https://digitalrepository.trincoll.edu/facpub

Part of the European History Commons 


\title{
Stendhal and the Trials of Ambition in Postrevolutionary France
}

\author{
Kathleen Kete
}

The most audacious act in French literature may be the most misunderstood. To be sure, Julien Sorel's attempted murder of Mme de Rênalat the elevation of the host, at the sacrifice of the mass - was an act of passion, the act of a man maddened by ambition that was thwarted at the moment of its climax by the woman he had loved. The story of "un ambitieux" presents itself in Le rouge et le noir as a nightmare of democracy, of aspirations grasped and lost. In the words of Michel Crouzet, Julien stands at the scene of his crime and at his trial as both "witness and victim of the egalitarian passion and the resentment that is its constituent part." It is the negativity, not the savagery, of Julien's crime that arrests readers of Le rouge et le noir and introduces Stendhal into the pantheon of French intellectuals who have chosen liberty, even if in death, over bourgeois mediocrity and materialism: "In shooting Mme de Rênal, he turns his back on power, "he saves himself, forever, to the point of death, one might say, from ambition." 2

But how discordant with nineteenth-century values was Julien's iconic rejection of competitive individualism? The intriguing problem of ambition in postrevolutionary France has generated surprisingly little attention, though it may be central to the way we understand lib-

Kathleen Kete, associate professor of history at Trinity College in Hartford, Connecticut, is author of The Beast in the Boudoir: Petkeeping in Nineteenth-Century Paris (Berkeley, CA, 1994). She is completing a book on the problem of ambition in postrevolutionary France.

An earlier version of this essay was presented to the Nineteenth-Century French Studies Colloquium at Pennsylvania State University in 1998 and as part of a presentation to the New York Area Seminar on French History at the New School for Social Research in 1999. The author wishes to thank the anonymous reviewers and the guest editors of this issue for their help with this essay and the editors of French Historical Studies for their warm encouragement. She is also grateful to Patrice Higonnet, Dan McGrath, and Marie-Claire Rohinsky.

1 Michel Crouzet, "Notice sur Le rouge et le noir," in Stendhal, Le rouge et le noir, ed. Michel Crouzet (Paris, 1964), 27.

2 Ibid., quoting from Gilbert Durand, Le décor mythique de la Chartreuse de Parme (Paris, 1961).

French Historical Studies, Vol. 28, No. 3 (Summer 2005)

Copyright $@ 2005$ by the Society for French Historical Studies 
eralism. More than thirty years ago Theodore Zeldin wrote about the cultural hesitations shaping French response to the promise of competitiveness, to the "free play of competition" ordered by the Napoleonic Codes. ${ }^{3}$ His two-volume work, France, $1848-1945$, began with a section on ambition that described the expectations and desires of doctors, notaries, industrialists, bankers, bureaucrats, peasants, and workers as a means of explaining the resilience of traditional norms in modern France. ${ }^{4}$ Economic historians of the same generation made a similar point, stressing the importance of the family firm and its values of security and safety over the behaviors of risk in accounting for the contrast between the French and British economies. In news reports today we hear echoes of these arguments as commentators cite preferences for leisure over income to explain the apparent weakness of France compared to the United States in the global economy. They also invariably describe Jacques Chirac's main rival as the ambitious Nicolas Sarkozy, sometimes denigrating, sometimes celebrating, him as Anglo-Saxon in style. Despite the contemporary understanding of ambition as a passion - the liberal passion par excellence (burned in "effigy" along with selfishness, discord, and other disruptive vices at the Festival of the Supreme Being in 1794) $)^{5}$-it has been overlooked in the studies of this subject that are beginning to rejuvenate the cultural history of modernizing Europe. ${ }^{6}$

The most noteworthy evidence about resistance to ambition as a cultural ideal can be found in the medical literature of the period, a point made by Zeldin and developed more fully by Jan Goldstein in her landmark history of French psychiatry. ${ }^{7}$ Ambition could make one pale, shaky, blind, and eventually insane. Ambition could also lead to cancer, strokes, and heart attacks. "'But the most usual end of this pas-

3 William M. Reddy, The Navigation of Feeling: A Framework for the History of Emotions (Cambridge, 2001), 204.

4 Theodore Zeldin, France, 1848-1945: Ambition and Love (Oxford, 1979). First published as the first of two sections of France, 1848-1945 (Oxford, 1973).

5 See the description of this festival in Le guide du Routard: Paris balades, ed. Yves Couprie et al. (Paris, 2001), 73-74.

6 Recent works include Reddy, Navigation of Feeling; Philip Fisher, The Vehement Passions (Princeton, NJ, 2002); and Gail Kern Paster, Katherine Rowe, and Mary Floyd-Wilson, eds., Reading the Early Modern Passions: Essays in the Cultural History of Emotion (Philadelphia, 2004). Daniel Gordon's work on sociability addresses early modern conceptions of the passions and the importance of these notions in shaping attitudes toward state and society (Citizens without Sovereignty: Equality and Sociability in French Thought, 1670-1789 [Princeton, NJ, 1994]). Albert O. Hirschman, The Passions and the Interest: Political Arguments for Capitalism before Its Triumph (Princeton, NJ, 1977), discusses changing views of self-interest, and of the passions overall, in early modern England and France.

7 Jan Goldstein, Console and Classify: The French Psychiatric Profession in the Nineteenth Century (Cambridge, 1987), chaps. 3-4. 
sion is melancholy and above all ambitious monomania." " 8 In the words of Jean-Baptiste-Félix Descuret, author of La médecine des passions: "The victim of this passion soon becomes pale and his brow furrows, his eyes withdraw into their sockets, his gaze becomes restless and anxious, his cheekbones become prominent, his temples hollow, and his hair falls out or whitens prematurely." 9

Goldstein stresses the conflation of "social commentary and medical diagnosis" in "the perception of many lay and medical observers that individuals in post-revolutionary society were likely to fall prey to the "torments of ambition." 10 The critique of ambition turned on the contrast of the old regime with the new. For Etienne Esquirol-whose research helped establish the monomania diagnosis in the developing field of psychiatry - as "the dominant passions of the era" change, so too do its dysfunctions. The madness of Don Quixote gave way in the Reformation to the madness of religious enthusiasm. ${ }^{11}$ In the Restoration and July Monarchy, "lunatics by ambition" believed that they were Napoléons, Caesars, and dauphins, "generals, monarchs, popes, and even God," Descuret warned..$^{12}$ "Put in more general terms," Goldstein writes, "the special monomania of the early nineteenth century was overweening ambition of all sorts, stimulated by the more fluid society that was the legacy of the Revolution." ${ }^{13}$ Fashionable, bourgeois-statistically more liable to hit the middle classes ${ }^{14}$ - monomanie ambitieuse was one of the defining diseases of the age. Little wonder that a quarter of the patients of the Bicêtre hospital and a tenth of the patients admitted to the Salpêtrière in 1841-42 were diagnosed as overly, indeed insanely, ambitious. ${ }^{15}$

This essay plucks Julien from the history of rebel intellectuals and sets him down on the earthier field of postrevolutionary culture that viewed ambition as an illness which, as influential guides to careers also warned, could lead to its victim's distress. ${ }^{16}$ Stendhal's novel parallels the

8 Jean-Baptiste-Félix Descuret, La médecine des passions; ou, Les passions considérées dans leurs rapports avec les maladies, les lois et la religion (Paris, 1841), 579. The translation is Zeldin's (Ambition and Love, 91).

9 Descuret, Médecine des passions, 579.

10 Goldstein, Console and Classify, 160. Goldstein explains that the phrase torments of ambition comes from the article on folie in the Dictionnaire des sciences médicales (Paris, 1812-22).

11 Goldstein, Console and Classify, 158-59. Goldstein is summarizing Esquirol. The quoted phrase is Goldstein's.

12 Descuret, Médecine des passions, 579.

13 Goldstein, Console and Classify, 159.

14 Ibid., 161-62; Descuret, Médecine des passions, 580.

15 Goldstein, Console and Classify, 161.

16 See Zeldin's discussion (Ambition and Love, 88-98) of Edouard Charton, Guide pour le choix d'un état ou dictionnaire des professions (Paris, 1842), and Paul Jacquemart, Professions et métiers: Guide 
drama of the psychiatric case study. But Stendhal imagined two fictions, not just one, to deal with the problem of ambition, and that is the central claim of this essay. I also look at the strategies that allowed Stendhal in the course of his own life to escape the conundrum that destroyed Julien. Caught between the open sky of the liberal promise and the beckoning tomb of its critique, vocation - the quasi-religious, irrepressible, redeeming call to his life's work-came to stand for Stendhal as an attractive alternative to his hero's violent end. As Tzvetan Todorov does in his essay on Benjamin Constant, this essay treats the life of Stendhal on a par with the works, "as one among other forms of expression," indeed as "a particularly eloquent" one, an approach that Stendhal, who saw himself as his family's "masterpiece," might applaud. ${ }^{17}$ The focus on biography works to explain how, given the resistance to competitive individualism that the medical and other evidence suggests, success was possible and ambition palatable, as was flamboyantly the case in the capital of modern life.

The plot of Le rouge et le noir is well known but bears review in the context of our theme. The son of a carpenter - a peasant operating a sawmill on the outskirts of Verrières - Julien Sorel hates his brutal, male, and mean family. The intelligent and delicate boy - he has a pale feminine face, marked by luminous eyes, topped by thick dark hair - is patronized by the elderly, loving Father Chélan, who teaches him Latin. On the sly, he reads Rousseau and Napoléon (in the Mémorial de SainteHélène) and dreams of escaping from Verrières.

With the recommendation of Father Chélan, Julien, now nineteen years old, becomes tutor to the three sons of the mayor of Verrières. He seduces their mother, Mme de Rênal, who falls in love with him. When scandal about the affair breaks out, Father Chélan's influence gains him entry into the seminary at Besançon. There the abbé Pirard, a Jansenist like Father Chélan (a thinker against the grain), becomes his patron. When both Pirard and Julien are about to be forced out of Besançon, Pirard's influence lands Julien the position of private secretary in Paris to the marquis de La Mole, a member of one of the oldest aristocratic families. Julien seduces the daughter of the marquis, Mathilde, who falls in love with him. They become engaged to be married, and, Mathilde being pregnant, the marquis gives his consent. He changes

pratique pour le choix d'une carrière à l'usage des familles et de la jeunesse (Paris, 1892). Goldstein describes Charton's Guide as "a popular practical handbook on choosing a career" (Console and Classify, 13). 17 Tzvetan Todorov, Benjamin Constant: La passion démocratique (Paris, 1997), 30; Stendhal, Vie de Henry Brulard, in Oeuvres intimes, ed. Victor del Litto, vol. 2 (Paris, 1982), 777 (on Stendhal as his grandfather's production, see 906). 
Julien's name to the chevalier de La Vernaye, buys him a commission in the cavalry, and begins to arrange for the marriage settlement.

As Julien is congratulating himself and plotting further advancement, the marquis receives a letter from Mme de Rênal denouncing Julien as a seducer and adventurer. "Poor and covetous," Mme de Rênal writes to Mathilde's father, "it was by means of the most consummate hypocrisy and through the seduction of a weak, unhappy woman that that man sought to further himself and become somebody." Advised by Mathilde that "all is lost," Julien travels to Verrières and shoots Mme de Rênal at church. ${ }^{18}$

The passion to succeed propels Julien from one point in the story to the other, as readers will notice. Ambition dominates his thoughts. It is the most striking aspect of his personality, from the moment we are introduced to him in chapter 4 . There Julien has just set aside his dreams of military success and begun his studies with Chélan. "One fine day," the narrator tells us, Julien stopped talking about Napoléon: he announced his intention of becoming a priest and was to be seen constantly in his father's sawmill, busy memorizing the Latin Bible the curé had loaned him." 19

Julien is keen on taking holy orders because he calculates that in the context of the Restoration, the priesthood will reward him most. "When people began to talk about Bonaparte," he reflects, "France was afraid of being invaded; military talent was badly needed and in fashion. But today, you see priests at forty with incomes of one hundred thousand francs; that is, getting three times as much as the most famous generals in Napoléon's divisions." But the idea that, like Napoléon, he could rise from nothing to greatness - "that Bonaparte, an unknown and penniless lieutenant, had made himself master of the world by his sword"-continues to absorb his thoughts even during sexual encounters with Mme de Rênal. ${ }^{20}$ Stendhal allows Julien only briefly to forget his obsession with success, as he does in the memorably dark garden at Vergy in the aftermath of kissing the naked arm of Mme de Rênal:

Julien gave no further thought to his dark ambition, or to his scheme, so difficult of execution. For the first time in his life, he was swept away by the power of beauty. . . .

But this emotion was pleasure and not passion. On the way back to his room, he had but one delight in mind, that of returning to his favorite book [the Mémorial de Sainte-Hélène]; at twenty, one's idea of

18 Stendhal, The Red and the Black, trans. Lloyd C. Parks (New York, 1970), 450, 449.

19 Ibid., 33.

20 Ibid., 34 
the world and the impression one intends to make on it prevail over everything else. ${ }^{21}$

Stendhal continually allows Julien to be stimulated by the sight of worldly success, as when the bishop comes to Verrières. "His ambition [was] roused again by the example of the bishop's youth. . . . So young . . . to be Bishop of Agde!" Julien exclaims. "And what does the living come to? Two or three hundred thousand francs, perhaps." 22

Indeed, ambition drives Julien's lust. Again in the dark garden at Vergy, when for the first time Mme de Rênal herself secretly takes his hand and holds it, Julien's ambition again dominates his feelings: "This action roused the ambitious youth; he wished it could be witnessed by all those proud nobles who, at table, when he was sitting at the lower end with the children, would look at him with such a patronizing smile." As the narrator tells us in chapter 16, "The Next Day," Julien is "still in love with ambition," not with Mme de Rênal, or he is unaware of his love for her because of the hold ambition has over him. ${ }^{23}$

The disease of ambition is revealed in the course it takes in Julien's life. The narrator asks us to imagine that Julien has been mad by ambition intermittently since his youth. "From his earliest childhood on," the narrator tells us, "he had had moments of exaltation." He would see himself in Paris "as Napoléon had one day done, attracting beautiful women by his glamorous feats." From the age of fourteen, when he realized that the (liberal) justice of the peace has been corrupted by the legitimists, his ambition became a monomania: "The building of the church and the justice of the peace's decisions suddenly made things clear to him. A notion came to his mind that drove him almost crazy for weeks, and finally took hold of him with the overwhelming force of the first idea that a passionate soul imagines it has discovered." 24 As Shoshana Felman points out, the word folie (madness) and its variants appear 209 times in Le rouge et le noir. As in the other completed novels, Armance and Charterhouse of Parma, "the frequency increases from one section to another. A pattern, a schema, of frequency emerges as a constant that seems to mark a structural tendency of the Stendhalian novel - that of a growing frequency, of a crescendo of "folie." 25

The breaking point for Julien, the moment when ambition becomes insanity, comes at the exact moment when he is within reach

21 Ibid., 75.

22 Ibid., 115.

23 Ibid., 88, 99.

24 Ibid., 33, 34

25 Shoshana Felman, La "folie" dans l'oeuvre romanesque de Stendhal (Paris, 1971), 24, 26. 
of his goals. "Julien was drunk with ambition," the narrator tells us when describing him at the camp of the Fifteenth Regiment of Hussars. "Lieutenant for barely two days and through a favor," he is dreaming of becoming a commander in chief. He is in the "middle of a rapture of the most unbridled ambition" when Mathilde's message reaches him. ${ }^{26}$ And he sets off to kill.

Julien's behavior - his determination to succeed, his suicidal violence when thwarted-would not have surprised a French psychiatrist in the 1820s, certainly not Esquirol, whose role in developing the profession of psychiatry was equaled only by that of his mentor, Philippe Pinel. In his 1819 essay on monomania Esquirol describes the temperament of monomaniacs in ways that will remind us of Julien's own: "Their ideas are exaggerated. Their passions are very strong. They are dominated by ambition and pride. These individuals will become monomaniacs when stimulated by thoughts of greatness, of riches, of bliss." Like Julien, who is distant from his family, hard to get close to, and emotionally labile, monomaniacs are alienated: "They express little affection for their friends and relations or else their attachments are extreme. Often they treat with disdain the people they cherish the most." They are quick to anger, "easily offended, extremely irritable. . . highly impressionable, strong-willed, defiant toward restraint, easily angered, they slip quickly into fury." ${ }^{27}$ Is this not Julien, whose anger Jules C. Alciatore has shown in his essay "Stendhal et Pinel" to fit the description of angry lunatics drawn by Pinel in the Traité médico-philosophique sur l'aliénation mentale, ou la manie? ${ }^{28}$

The shape of Julien's life fits the pathology of lunacy clearly described in the Dictionnaire des sciences médicales. There Esquirol explains that certain people are especially predisposed to monomania by "selfesteem, vanity, pride, ambition; they abandon themselves to their ideas, to their exaggerated hopes, to their outrageous pretensions." Disease sets in, typically, only after a reversal of fortune. "It is remarkable, however, that almost always those individuals who fall into monomania have been stricken by some reversal of fortune, have been stripped of their hopes, before becoming sick." ${ }^{29}$

26 Stendhal, Red and the Black, 449.

27 Etienne Esquirol, "Monomanie," in Dictionnaire des sciences médicales, vol. 34 (Paris, 1819), 116.

28 Jules C. Alciatore, "Stendhal et Pinel," Modern Philology 45 (1947): 130-33. Alciatore also shows how Stendhal borrows directly from Pinel both in Histoire de la peinture en Italie and in Vie de Rossini to describe the "dangers du génie." He argues, however, that Stendhal suffered from melancholy. Alciatore does not mention monomania.

29 Esquirol, "Monomanie," 124. 
Esquirol explains as well that before the lunatic's final step into insanity (démence), he behaves reasonably, retaining his grip on reality: "He reasons and makes decisions very well." ${ }^{30}$ Is this not Julien, whose whole life, up to the moment of the crime, is marked by a series of successes checked by failure but always guided forward by cold, effective logic?

Esquirol abstracts the monomaniacal personality in the Dictionnaire des sciences médicales, but more typically Pinel and Esquirol describe the disease by presenting case studies-historiettes (little stories), Pinel called them in his Traité-such as the following, which for the most part are gathered under the rubric "stifled ambition." ${ }^{31}$ For example, we meet a law student friend of Pinel's youth who is so obsessed with succeeding at his studies in Paris that he spends his days and nights studying - to the exclusion of eating and sleeping. Naturally, his health suffers. His alarmed and loving parents return him to the provinces, thus precluding his success at law. Distraught, inconsolable at his failure to succeed, he walks into the woods and shoots himself dead.

Pinel also presents the case of a "hero of the Bastille," a soldier who had participated in the attack on the Bastille but who has gone insane because his heroism was not rewarded by a promotion to colonel. We also read about a sixteenth-century merchant who suffers a commercial setback and becomes mad-a madness marked by his conviction that he is bankrupt despite patent evidence to the contrary.

That Stendhal shared an interest in Pinel is well known. Victor del Litto explains that in January 1805 Stendhal went to the medical school to read Pinel's Traité, but the doors were closed to him. A year later, after being urged by his friend, Félix Faure, "whose sister was showing signs of mental illness," he read the book, recommending it as well to his own sister, Pauline. In 1810 he read it again. ${ }^{32}$

What particularly impressed Stendhal was the chapter "Art of Counterbalancing the Human Passions by Others of Equal or Superior Force, an Important Part of Medicine," where Pinel explains that the doctor "often sees no other remedy than to not restrain the patient's natural inclinations, or to counterbalance them by even stronger impulses." 33 We know that this insight of Pinel's impressed Stendhal. Del Litto explains that "shortly after reading [Pinel], Stendhal makes allu-

30 Ibid., 125.

31 "Stifled ambition" and "little stories" are Goldstein's translations of Pinel's terms. Goldstein summarizes Pinel's case studies discussed here in Console and Classify, 80-84.

32 Victor del Litto, La vie intellectuelle de Stendhal: Genèse et évolution de ses ideés, 1802-1821 (Paris, 1962), 287nn63, 65; 288.

33 Pinel, Traité médico-philosophique sur l'aliénation mentale, ou la manie (1800; rpt. Geneva, 1980), 237, 238. 
sion in a letter to Pauline to a corollary of these ideas," writing that "it is a question of forming new habits, that is the most important thingread La manie by Pinel, and you will perceive the importance of this principle.'" Del Litto shows as well that, "in anticipation of applying the principles taken from La manie he had particularly made note of the page that addressed the problem of treating the passions." Finally, del Litto notes Stendhal's January 1806 Journal entry: "I observed yesterday evening . . . 'the storms of passions,' . . . those grand passions that may be healed only by the means indicated by Pinel in La manie." ${ }^{34}$

In the case of the soldier at the Bastille, Pinel explained, lunacy could be cured by satisfying his ambition and giving him a commission in the army. The sixteenth-century merchant could be healed by replacing one passion with another. In the latter case, Pinel found "a fortuitous operation of the strategy of counterbalancing." ${ }^{35}$ The merchant, not cured by being shown that his coffers were indeed full of gold, recovered nicely when the passion for religion replaced his passion for commercial success. ${ }^{36}$

The cure of lunacy by ambition-monomanie ambitieuse-entailed either the satisfaction of ambition or its replacement by other passions. In the curing of monomania, Pinel argued that the dramatic element is very important. The staging of "pious frauds," "innocent ruses"- that is, the setting up of a fictive event to "strongly jolt the imagination"was a practice for which Pinel became known. As Goldstein explains, "An insanity viewed as imagination gone awry can be countered by a procedure that 'shakes up' the imagination in order to dislodge the erroneous idea that has taken hold or to rupture the "vicious chain of ideas." " 37

Pinel reported the case of a tailor convinced during the Terror that he was to be brought before the Revolutionary Tribunal for having made an unpatriotic remark. No longer working, no longer eating, he had been spending his days prostrate on the pavement outside his home waiting for his arrest when he was placed in the asylum. To cure him, Pinel staged an interrogation by members of the tribunal, whose parts were played by young doctors being trained by Pinel. They came to the Bicêtre dressed in black robes and with all the trappings of their office to examine the tailor on his business, his activities, the journals he had been reading - in general, on his patriotism. Afterward, in Pinel's

34 Del Litto, Vie intellectuelle de Stendhal, 289, 288, 289.

35 The phrase is Goldstein's (Console and Classify, 88).

36 Pinel, Traité, 239.

37 Goldstein, Console and Classify, 93. Pinel was influenced by the practices of (English) charlatans (ibid., 84). 
words - "in order to shake his imagination even more strongly" - the chair of the committee made a formal, loud, and long declaration of his innocence. ${ }^{38}$

I see Julien Sorel's attack on Mme de Rênal as a type of therapeutic theater, one that Stendhal uses to cure Julien of his ambition, a kind of shock therapy that, like Pinel's cure of the tailor, jolts the sufferer out of his ambition; in its stead Julien feels the passion of love. The compression of the scene sets the stage for his transformation: the sparsely described church, tinted red in our imagination; our expectancy as we hear the three bells announcing the start of mass; our concern when we see the bowed head of Mme de Rênal and the elevated host; the tinkling of the bells. ${ }^{39}$

We know Julien is mad when he shoots Mme de Rênal because afterward he is dramatically sane. When chapter 35, "A Storm," gives way to the next, "Stendhal speaks three times . . o of Julien's coming back to himself." We should note here the same terms used by Pinel to denote a lunatic's cure. For Pinel, a cure is a patient's "return to one's true self, a retour sur lui-même, and an act of being ramené à lui-même." 40 In the narrator's terms, after shots were fired, "Julien stood motionless; he saw nothing." 41 "Quand il revint un peu à lui"-literally, when he had returned a bit to himself - "when he had somewhat recovered his senses, he noted that all the faithful were running out of the church." 42

"'By George! the game's up!' he said aloud as he came to"- "en revenant à lui." 43 Later, after sending off a farewell letter to Mathilde, Julien feels "somewhat recovered," though "thoroughly wretched for the first time." When he is told that Mme de Rênal lives, Julien begins to repent. "By a coincidence that saved him from despair, in the very same instant, the state of physical irritation and near madness into which he had been plunged ever since his departure for Verrières came to an end." In prison, Julien experiences his epiphany: "He saw everything from a new angle," the narrator explains. "His ambition was gone." 44

Le rouge et le noir shares with the medical critique an awareness of the social hazards of ambition, while refraining from offering an ideo-

38 Goldstein summarizes the case in Console and Classify, 83. My summary is from reading of Pinel, Traité, 233. The quotation is on 236.

39 The three bells are "a well-known signal in French villages that, after the various morning chimes, announces that Mass is about to begin" (Red and the Black, 451).

40 Donald M. Frame, "Afterword," in Red and the Black, 532; Goldstein, Console and Classify, 99. Goldstein is quoting Pinel, Traité, 59, 65.

41 Stendhal, Red and the Black, 452.

42 Stendhal, Rouge et le noir, 448; Stendhal, Red and the Black, 452.

43 Stendhal, Red and the Black, 452; Stendhal, Rouge et le noir, 448.

44 Stendhal, Red and the Black, 454, 456, 457. 
logical cure. What Stendhal accomplishes in his novel is the opening up of an "angle of access" on the trials of ambition in postrevolutionary France. ${ }^{45} \mathrm{He}$ is making a case - though not a legal or moral one for or against Julien Sorel, which already has been established in the plot. Julien admits his guilt in pretrial formalities. He refuses to offer a defense of jealous rage and insists that his crime was premeditated: "His lawyer, a man of rules and formalities, thought he was crazy and, like the public, was convinced that jealousy had shoved the gun into his hand. One day he ventured to let Julien know that this allegation, true or false, would make an excellent plea for the defense. But in the wink of an eye, the accused became his incisive and passionate self once more." ${ }^{46}$ Julien's trial contrasts with that of Antoine Berthet, who offered in defense of his prototypical crime the "irresistible derangements of love" and whose prosecutor successfully argued that Berthet was motivated by "disappointed ambition": "disabused of his ambitious dreams, understanding too late that he could not reach the goal that his pride proposed, Berthet, stripped of his hopes, would perish; but his rage would drag a victim along with him to the tomb that he dug for himself!" 47

The trial of Julien is a case in the terms fashioned by English romantics in which "anomalous combinations of circumstances" are presented not to pose solutions but to "catch the conscience" of his age. ${ }^{48}$ Julien's defense, "I have not the honor of belonging to your class," is suicidal when presented to a jury packed in his favor (through the agency of Mathilde). The completion of his thought, "In me you see a peasant in revolt against the baseness of his lot," captures the modern political imagination by shifting his problem from the particularhis attempted murder of Mme de Rênal (who "had been like a mother to me") - to the collective guilt of the jurors, who, in Julien's words, "would like to punish through me and discourage forever a whole class of young men who, born to an inferior position in society and, so to speak, oppressed by poverty, have had the luck to obtain a good education and the audacity to mingle with what the rich in their pride call society." 49

45 James Chandler, England in 1819: The Politics of Literary Culture and the Case of Romantic Historicism (Chicago, 1998), 298.

46 Stendhal, Red and the Black, 475-76.

47 Stendhal "almost certainly," in the view of Pierre-Georges Castex and other critics, read about Berthet's trial in the Gazette des tribunaux and Le pirate. Castex reproduces these reports in his edition of Le rouge et le noir (Paris, 1973), 650. The quotations are from 664 and 665. Castex also discusses the related trial of Lafarque, a cabinetmaker who kills his mistress.

48 Chandler, England in 1819, 295, 298.

49 Stendhal, Red and the Black, 483. 
No solution to the social question, however, is effected in the plot. Julien, "decapitated by the bourgeoisie," to paraphrase Maksim Gorky, meets the fate of all Stendhal's heroes. ${ }^{50}$ In the words of the midnineteenth-century critic Hippolyte Babou, "Octave settles the final question with suicide, Julien with murder, and Fabrice, too cruelly stricken to have the energy either to kill or to die, gives in to the suffering which, little by little, spreads through him like a deadly chill." ${ }^{51}$ All of the novelist's heroes, "to take up the expression of Stendhal, end as 'fiasco." " 52 The stories of all of Stendhal's characters abruptly end, their arguments withdrawn. Consider also the case of Lamiel, whose heroine was abandoned in Paris in chapter 25, independent but uncertain after her successful translation from the provinces.

The open arc of the Stendhalian novel contrasts with the closed solutions to its problems forwarded by influential interpreters, whose views converged to form a consensus in the twentieth century. The nationalist Right in France in the early twentieth century celebrated the violent withdrawal of the Stendhalian hero from society as a sign of his author's "anti-bourgeois," "anti-republican," "anti-democratic," "aristocratic elitism." ${ }^{53}$ For the Stalinist Left, Stendhal's failure to solve the social problem posed in his plots is due to his regrettable myopia, to the fact that "he did not understand or recognize which new class was the true inheritor of the revolutionary tradition." ${ }^{54}$ The fate of his heroes is "the manifestation of that absence of historical perspective." 55 Nonetheless, Soviet youth were encouraged to read Stendhal, "as an adversary of bourgeois society and the capitalist regime," in the words of Gorky (who had been "especially seduced by Julien Sorel") and of Victor Vinogradov, who saw Stendhal's oeuvre as "imbued with the great revolutionary ideas, which form a precious part of the inheritance that the proletariat receives and develops solicitously." 56

To see Julien as embodying generally feared ambition-and not simply opposition to a class - is to step out of the binary opposition of rebel intellectual and complacent bourgeois society that has been institutionalized in the right- and left-wing interpretations of the novel.

50 Quoted in Fernand Rude, Stendhal et la pensée sociale de son temps, ed. Robert Mandrou (Paris, 1967), 254.

51 Quoted in Emile Talbot, La critique stendhalienne de Balzac à Zola (York, SC, 1979), 8.

52 Rude summarizing Victor Vinogradov in Stendhal et la pensée sociale, 256.

53 See Eugen Weber, Action Française: Royalism and Reaction in Twentieth-Century France (Stanford, CA, 1962), 81, 80.

54 Vinogradov, Stendhal et son temps [in Russian] (Moscow, 1938), quoted in Rude, Stendhal et la pensée sociale, 256.

55 Ibid.

56 Rude quotes and describes Gorky and summarizes Vinogradov in Stendhal et la pensée sociale, $255,254,257$. 


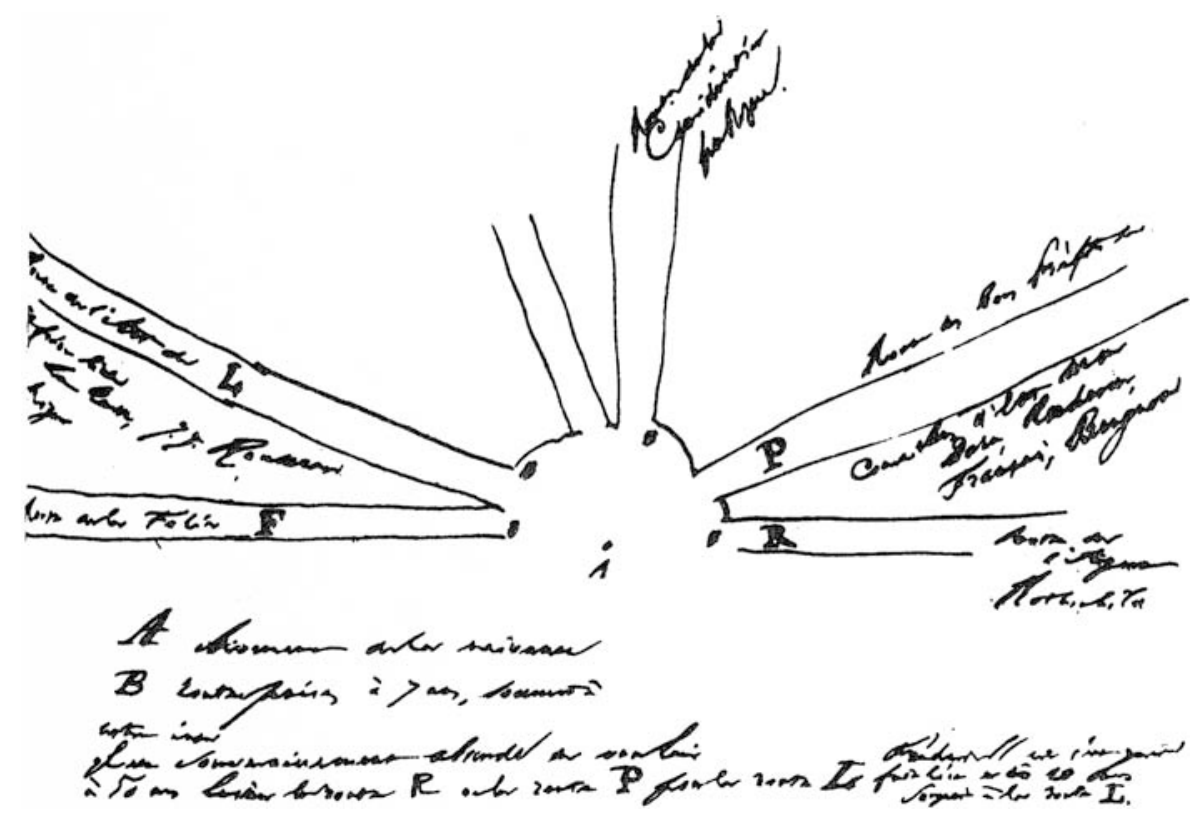

Figure 1. Stendhal's sketch of life choices

It also is to see postrevolutionary France in broader cultural terms, as caught between a traditional resistance to individualism and the appeal of modernity, with no easy options in sight.

In the next section of this essay I review the life of Stendhal with the goal of understanding how he could escape the impasse of his alter ego, Julien. How could ambition not lead to the ethical plane shared by Père Sorel, M. de Rênal, the abbé de Frilair, the bishop of Agde, members of Julien's jury, and almost everyone in Stendhal's "Chronicle of 1830 ," including Julien himself, for a time?

Consider the map of contemporary life sketched out twice by Stendhal in his unfinished autobiography, the Vie de Henry Brulard (fig. 1). ${ }^{57}$ With $A$ being the moment of birth, $R$ the "route to riches," $P$ the "route of good prefects and members of the Conseil d'Etat," and $L$ the "route to getting oneself read," Stendhal describes the ambitions of his generation. Del Litto suggests that the "road to madness," the route $F$, is the route with which Stendhal most closely identified. ${ }^{58}$ Perhaps. But it is the inflection, $B$, the "roads taken at age seven, often

57 Stendhal, Vie de Henry Brulard, 813. See also the earlier illustration on 671.

58 Del Litto, "Notes et variantes," in Stendhal, Oeuvres intimes, 2:1408. The note on page 1408 refers to page 671 of the text. 
without our knowing it" - to borrow Stendhal's word elsewhere, one's "vocation" 59 - that he invokes to save himself from the ambiguities of his considerable success.

The author's life is as emblematic as Julien's. As Henri Beyle, Stendhal grew up in the provincial Enlightenment, a cultural world punctured not by the outbreak of Revolution - his beloved grandfather was a "patriot" in 1788, five votes short of being elected to the Estates General $^{60}$ - but by Jacobinism. Henri's ecstatic reaction to the news of the execution of Louis XVI - "I was gripped by one of the most intense feelings of joy I have ever felt in my life"-illustrated the gulf between his ten-year-old self and the older generation. In Vie de Henry Brulard Stendhal famously describes his detested father's sigh as he reported the news of what those "monsters" had done. "'It's all over,' he said with a deep sigh. 'They've murdered him.," 61

In his unfinished Mémoires sur Napoléon (1836-37) Stendhal laments another chasm: between his generation, shaped in childhood by "enthusiasm for Republican virtues," and those men born after the Revolution began "who were fifteen years old in 1805 as they began to look around and see as their first object of interest the plumed velvet caps of the dukes and counts recently created by Napoléon," that is, who were shaped simply by the outward signs of material success and their "puerile ambition." 62

Stendhal's historical place in this hinge generation allows us to explore through him the trials faced by those whose "inherited values" are shaken or dissolved by the trajectory of the French Revolution. ${ }^{63}$ This use of Stendhal reflects renewed interest within the field of cultural history in the notion of the representative person-the exemplary character who acts as a "cultural synecdoche," who represents the whole by its part, as James Chandler notes in his literary history, England in 1819. As recent work in The New Biography has affirmed, "cultural politics are most easily examined as well as empathetically imagined in the individual life." 64 This methodology is particularly apt for

59 Stendhal, Vie de Henry Brulard, 699.

60 Though Stendhal's grandfather was concerned already in 1789 by the "energy" of those deputies beholden to him. Stendhal, Life of Henry Brulard, trans. John Sturrock (New York, 2002), 57,59 .

61 Stendhal, Vie de Henry Brulard, 633, 634.

62 Stendhal, Napoléon: Vie de Napoléon, mémoires sur Napoléon, ed. Catherine Mariette (Paris, 1998), 257, 258.

63 Victor Brombert, "Introduction," in Stendhal: A Collection of Critical Essays (Englewood Cliffs, NJ, 1962), 1. On the "cohort coming of age in the Restoration's first decade," see Alan Spitzer, The French Generation of 1820 (Princeton, NJ, 1987), 3.

64 Jo Burr Margadant, "Constructing Selves in Historical Perspective," in The New Biography, ed. Jo Burr Margadant (Berkeley, CA, 2000), 7. 
the study of the early nineteenth century. ${ }^{65}$ It was postrevolutionaryromantic-Europe, after all, that posed the question of the relationship between individuality - the particular - and culture overall. Goethe's life, for one, was "consumed" by the quest to understand "this whole process whereby an individuality comes to be a unique self, and at the same time a representative of its world." 66

But how are new cultural habits formed? On the 18 BrumaireNovember 9, 1799-Henri Beyle was sixteen years old and on the road close to Paris, to his freedom, as he thought, from Grenoble and a stifling family life. What baggage did he carry with him? What did he leave behind? In this section we encounter Stendhal through his autobiographical fragments, the Souvenirs d'égotisme (1832) and the Vie de Henry Brulard (1835-36), where we see a performance of selves, or possible selves (masks in the terms of the Stendhalians), as he experiments with the choices open to his generation. ${ }^{67}$

Should he be a lawyer like his father or a great writer like Molière? The law is the choice his parlementaire father would have made for him. Or should he be an engineer or mathematician, the career goals of a graduate of the Ecole Polytechnique? As Grenoble's top candidate for admission, Stendhal's failure to matriculate in Paris surprised his friends and relations. Should he be an officer in Napoléon's army? He resigned his commission though his powerful relations, the Darus, had had him promoted, without cause, to lieutenant in the Sixth Dragoons. Perhaps he should be a capitalist? His venture as an importer-exporter of colonial goods in Marseille also went awry. He considered trying his fortune in Louisiana. Should he be a government official, a prefect, or a peer of France like his old friend Félix Faure? Stendhal was a provisional commissaire des guerres in 1806, auditeur au conseil d'Etat and inspecteur du Mobilier et des Bâtiments de la Couronne from 1810, but, as he famously said, "he fell with Napoléon." 68

That ambition focused the imagination of Stendhal is clear from his earliest writings. In Paris in 1802 he began and abandoned several great projects, including a reworking of the Odyssey, Hamlet, and Lucan's The Civil Wars. Stendhal's Odyssey would have centered on Antinöus, an "ambitieux parfait," in Stendhal's words, understood as one who uses

65 It was launched for social history by Natalie Zemon Davis with The Return of Martin Guerre (Cambridge, MA, 1983) and by Carlo Ginzburg with The Cheese and the Worms (Baltimore, 1980). 66 Chandler, England in 1819, 176n45. Chandler is quoting Karl J. Weintraub, The Value of the Individual: Self and Circumstance in Autobiography (Chicago, 1978).

67 On "multiple selves," see Margadant, "Constructing Selves," 7. On "performing lives," see ibid., 1-25.

68 Stendhal, Life of Henry Brulard, 15. 
his friends and lover to further his own dreams of power. ${ }^{69} \mathrm{He}$ worked on Hamlet for several weeks, The Civil Wars as well. Stendhal's project for the latter book is lost. But Lucan's story of the fall of the Roman Republic was well known, esteemed "among the philosophes and their circles," according to del Litto, "and still more so during the Revolution." Gaspard Dubois-Fontanelle, Stendhal's professor of literature at the Ecole Centrale, wrote in 1799 that it provided "a great lesson." In explaining its place in the curriculum he noted that "its subject is the struggle of liberty against ambition and the defeat of the former." 70

But Stendhal was also worried about a corollary issue. Why do some people succeed and others fail? Why had so many of Stendhal's fellow Grenoblois - Faure, but also Casimir Périer, Louis Crozet, and Edouard Mounier-flourished under the new regime, and why had he, the focus of his family's hopes, landed as consul in Civitavecchia, the only ugly city in Italy, as filthy as Grenoble, ${ }^{71}$ and bullied by his assistant?

These are the questions that flow through Stendhal's unfinished memoirs. The self revealed in Vie de Henry Brulard, especially, seems to dovetail with that invented for Julien. The lives of each are driven by ambition, this way and that. Stendhal reflects in Henry Brulard that although when young he "was or believed [he] was ambitious; what worried [him] about that supposition was that [he] didn't know what to hope for." 72 What gives the lives of Julien and Stendhal their meaning is their arrest of that drive to succeed.

Both Julien's father and M. de Rênal seem derived from Chérubin Beyle, or his son's experience of him. Chérubin was deputy mayor of Grenoble in 1804, while Rênal was mayor of Verrières. Each was upwardly mobile. Chérubin, "ambitious for himself and his family," was a lawyer. ${ }^{73}$ A procureur at first, he soon became an avocat, an office he hoped to pass on to his only son. ${ }^{74}$ His eyes were on the consistoire. "He was on the point of being made a consistorial; this was an ennobling distinction among lawyers which he spoke of in the way a young grenadier lieutenant speaks of the cross," Stendhal noted critically. ${ }^{75}$ As Crouzet explains in his life of Stendhal, for Chérubin Beyle

69 Del Litto, Vie intellectuelle de Stendhal, 97.

70 Quoted ibid., 103.

71 Michel Crouzet, Stendhal ou monsieur moi-même (Paris, 1999), 17; Victor del Litto, Vie de Stendhal (Paris, 1965), 11. Simon Schama gives a favorable description of eighteenth-century Grenoble in Citizens: A Chronicle of the French Revolution (New York, 1989), 272-74.

72 Stendhal, Life of Henry Brulard, 22.

73 Crouzet, Monsieur moi-même, 19.

74 Stendhal explains in Henry Brulard that after the death of his mother, his father had contemplated taking holy orders but was restrained by this desire to pass his profession on to his son. 75 Stendhal, Life of Henry Brulard, 78. 
that success would mean a great deal. On Henri's baptismal certificate, his father is described as "noble Chérubin Beyle." 76 The new position would give that nobility greater security. ${ }^{77}$

Like M. de Rênal, Henri's father hires a tutor for his son. The repellent M. Raillane is perhaps the model for the abbé de Frilair. "My father took him on seemingly out of vanity," Stendhal complained in Henry Brulard. "What an honour for a lawyer in the Parlement to take on for his own son the tutor who had come from M. Périer's house." 78 "His family, becoming more and more ambitious, hired a tutor for him," Crouzet explains. The father's decision "mimick[ed] in advance M. de Rênal."79

The alienation between Stendhal and his father is as profound as that between Julien and M. Sorel. Stendhal believed his father had never loved him for himself. "He didn't love me as an individual," he complained, but only as the conduit of the family name, of the father's hopes for the future. ${ }^{80}$ Julien's father, Stendhal imagines, cannot love him. He is so different from his brothers, so unsuited for carrying out the work of a prosperous sawmill. Stendhal's description of himself is apt for Julien: "an 'orange tree grown by the strength of its own germ in the middle of a frozen pond, in Iceland." " 81 Forced while in prison to accept a visit from his avaricious father - who "never loved me" 82 Julien is brought for the first time in his ordeal to the brink of despair. ${ }^{83}$

Other incidents mark the connection between Julien and Stendhal. The feeling Stendhal has whenever he returns and hears the sound of the cathedral bells in Grenoble, which recall to him his mother's funeral - "the dry, dismal sadness, unpitying, the sadness that is close to anger" - is reprised as well in Julien. ${ }^{84}$ The scene of Mathilde de La Mole's reading forbidden books from her father's library echoes Stendhal's secret reading of the Encyclopédie, jointly subscribed to by his father and grandfather, and La nouvelle Héloïse. ${ }^{85}$

And the disappointment with which Julien concludes his first sex-

76 Crouzet, Monsieur moi-même, 19.

77 Stendhal, Vie de Henry Brulard, 1375. Del Litto explains that the position awarded personal nobility. He would be "one of forty lawyers in the Parlement responsible for professional discipline" (Stendhal, Life of Henry Brulard, 78n1).

78 Stendhal, Life of Henry Brulard, 81-82.

79 Crouzet, Monsieur moi-même, 26.

80 Stendhal, Life of Henry Brulard, 78. Also: "My father . . loved me as the upholder of his name but not at all as his son" (ibid., 88).

81 Quoted in Crouzet, Monsieur moi-même, 41

82 Stendhal, Life of Henry Brulard, 499.

83 Stendhal, Rouge et le noir, 490.

84 Stendhal, Life of Henry Brulard, 43.

85 Stendhal refers to the joint ownership of the Encyclopédie in Vie de Henry Brulard, 856. 
ual encounter with Mme de Rênal, "My God! To be happy, to be loved, is that all there is to it?" concludes Stendhal's successful descent from the Alps - "the Saint Bernard, is that all there is to it?" - and is itself an echo of his first response to Paris, in $1799 .{ }^{86}$ As he explains in Henry Brulard, that "rather simple-minded astonishment and that exclamation have followed me all my life." "That state of astonishment and uneasiness into which a man who has just obtained what he has long desired may lapse," the narrator of Le rouge et le noir explains for Julien. ${ }^{87}$

When Julien writes cella instead of cela in a letter dictated by the marquis de la Mole, this echoes the mistake made by Stendhal in 1800 as a new clerk to Pierre Daru, secretary for war, described by Napoléon as "a regular workhorse, a man of rare capacities, my best administrator." ${ }^{88}$ In each case the humiliation is double-weighted. It comes not just from being made in front of an important person but from being made by a youth touted by his protectors as a paragon of learning, a prodigy, certain to succeed. ${ }^{89}$ "So this was the man of letters, the brilliant humanist who queried the merits of Racine and had carried off all the prizes in Grenoble!!!" Stendhal imagined his important cousin to be thinking. ${ }^{90}$

It is reasonable as well to emphasize the differences between Julien and the young author. Stendhal himself, as we saw, suggested in his Mémoires sur Napoléon that the generation that came of age in the Empire lacked the emotional depth of those who grew up with the Jacobins. Julien was younger still. His brief maturity was shaped by the Restoration. Alciatore has argued that "chance determined the destiny of Julien. All his misfortune comes from not having been born twenty years earlier." 91 The accident that he did not come of age with Henri Beyle determines his plot.

But the woes of Julien and Stendhal are accidental to the postrevolutionary context that they share. Martin Turnell suggests that the "fact that [Julien] belongs socially to the proletariat simply provides a particular setting for the study of a much wider problem and creates an additional obstacle to Julien's success.” For Turnell, writing in 1962, the wider problem is Julien's status as an "outsider": "Julien would have

86 Stendhal, Red and the Black, 96; Stendhal, Vie de Henry Brulard, 944. Stendhal describes this reaction to Paris in Vie de Henry Brulard, 900.

87 Stendhal, Life of Henry Brulard, 475; Stendhal, Red and the Black, 96.

88 Jonathan Keates, Stendhal (New York, 1994), 42.

89 Stendhal, Life of Henry Brulard, 423.

90 Ibid., 430.

91 Jules C. Alciatore, Stendhal et Helvétius: Les sources de la philosophie de Stendhal (Geneva, 1952), 209. 
been an 'outsider' in any class of society, and he is equally out of place in the world of his father, of the Rênals, and of the La Moles." 92

We can suggest something broader still, about the tensions within postrevolutionary France, which stemmed from the challenges of competition, regardless of class. Julien and Stendhal are versions of the same postrevolutionary self. According to Jean Starobinski's influential description, "In the reveries of metamorphosis in which he becomes Julien, Fabrice, Lucien, Lamiel, he changes face, body, social status, even sex, but it is always to tell his own life story while introducing greater fortune and greater misfortune. . . He begins his life anew in another body, the way one starts a card game with a new deal." 93 Each deal is guided by the same conventions. The principles that shape Stendhal's world are the same-for a time-as Julien's. Self-interest makes the world go around, passions shape our ideas, and we are who we are by virtue of our environment. These ideas were introduced to Stendhal in a general way at the Ecole Centrale. ${ }^{94}$ They became more specific through his reading of Claude Adrien Helvétius's De l'esprit and De l'homme in 1802-5 and his association with the Ideologues in Paris. ${ }^{95}$

In letters to his sister, Pauline, he quotes from Helvétius. "The passions are the sole motor of human behavior," he wrote in January 1803. The next day he continued with a list of "general principles" taken from De l'homme, including that "all our ideas come from our senses" and that "education alone makes great men; consequently, one has only to want to do so to become a genius." 96 And, del Litto explains, "it is again following Helvétius, one suspects, that he champions the 'shining principle' that self-interest is the determinant of all human behavior," as Stendhal urged Pauline to understand in February of the same year. Del Litto describes him as "steeped in the principles of Helvétius." 97 Victor Brombert, less approvingly, suggests that Stendhal had "serious indigestion from his consumption of Helvétius, Maine de Biran, Cabanis, Pinel, Destutt de Tracy." 98

In his work on the emotions in history William Reddy reminds readers of the influence of the Ideologues - or the orientation of ideas

92 Martin Turnell, "Le rouge et le noir," in Brombert, Stendhal, 21.

93 Jean Starobinski, "Truth in Masquerade," in Brombert, Stendhal, 126.

94 Del Litto, Vie intellectuelle de Stendhal, 39.

95 Stendhal claims that when he arrived in Paris in 1799, "I had for support only my common sense and my belief in Helvétius's l'Esprit” (Vie de Henry Brulard, 875). Del Litto says, though, that Stendhal probably had not yet read Helvétius for himself (ibid., 1504n4).

96 Del Litto, Vie intellectuelle de Stendhal, 41-42.

97 Ibid., 42, 41.

98 Victor Brombert, The Hidden Reader: Stendhal, Balzac, Hugo, Baudelaire, Flaubert (Cambridge, MA, 1988), 164. 
set by the collapse of both the Old Regime and Jacobinism-during the Directory but also the Empire. Though Napoléon abolished the Second Class of the Institut de France, which was a stronghold of the Ideologues, the pursuit of enlightened self-interest ${ }^{99}$ - its elevation to a moral good, liberating us from "providential design" 100 - was compatible with Napoleonic opportunism. The new civil order was shaped by competition.

These ideas clearly shape the character of Julien Sorel. They ostensibly shaped Stendhal's behavior as well. ${ }^{101}$ In a letter to the stepdaughter of Georges Cuvier (the Napoléon of science), whose salon he had frequented in the 1820 s, Stendhal says, "I assure you that no one has made a great fortune without being Julien." 102 Stendhal had practice trying. In 1806, after he failed in his friend's business in Marseille, Stendhal and his family begged the Darus to help him again. The Beyles wanted Henri to be made one of Napoléon's auditeurs du conseil d'Etat, a position created in 1803 that would bring prestige, access to the emperor, and entry to a lucrative career. ${ }^{103}$ "Nothing generous or heroic in that decision to tap the influence of the all-powerful Daru and to play to the limit the family connection," says Crouzet, as earlier Stendhal allowed himself to be promoted in Italy on the basis of a lie: "To legitimate that incredible string-pulling [coup de piston], the regiment falsely certified that he was already engaged in July 1800 and had served as sergeant at arms." 104

How did Stendhal escape the sacrifice of Julien, "fiasco-ed," brought to a dead end, as Julien embraced these principles, then dramatically jettisoned them? After being condemned to death for attempted murder, Julien contemplates the future he could have expected as the husband of Mathilde de La Mole: "Colonel in the Hussars, had we gone to war; secretary of a legation in peacetime; after that, ambassador . . . for I would soon know the ropes. . . . All my blunders would be pardoned, or rather, set down as accomplishments. A man of accomplishments, enjoying the best life has to offer, in Vienna or in London.” ${ }^{105}$ Even after being denounced by Mme de Rênal, Julien

99 Reddy, Navigation of Feeling, 202.

100 Charles Taylor, Sources of the Self: The Making of Modern Identity (Cambridge, MA, 1989), 321.

101 Crouzet, Monsieur moi-même, 118: "Alas, Stendhal created Julien out of his own experience of ambition, his passion to make his fortune at any cost."

102 Quoted in Dorinda Outram, Georges Cuvier: Vocation, Science, and Authority in Postrevolutionary France (Manchester, 1984), 50. Outram cites Louis Royer, Stendhal au jardin du roi: Lettres inédites à Sophie Duvaucel (Grenoble, 1930), 62.

103 Crouzet, Monsieur moi-même, 119.

104 Ibid., 77.

105 Stendhal, Red and the Black, 487. 
could have succeeded. The attack on Mme de Rênal - the crime, itselfis gratuitous, since he could still have made his fortune in exile, even after her damning letter to the marquis. La Mole offered to give Julien an income of ten thousand francs a year if he would leave the country, abandoning the deceived Mathilde: "If he is willing to live far away, beyond the frontiers of France, or better still, in America." 106

When Stendhal died, he had achieved something of Julien's dreams. He was a chevalier of the Legion of Honor, a former officer in the Grande Armée, a former auditeur du conseil d'Etat during the Empire, and the current French consul in Civitavecchia in the Papal Stateswhich, though an undesirable posting, afforded extended leaves in Paris for writing and socializing.

Stendhal's different course draws us into the patterns of thought of someone who worried deeply about the problem of ambition - that "thirst for positions and high offices," in his own definition ${ }^{107}$ - whose critique of competitive individualism had become his signature theme, but who had found within himself a way to reconcile his achievements to his residual old regime morality.

Stendhal's reconciliation begins with an examination of conscience, a habit drawn from his Catholic past. Both Souvenirs d'égotisme and Henry Brulard are introduced as such. "Let us see if, in making my examination of conscience, pen in hand, I will arrive at something real and that remains consistently true for me," is the explanation he gives in 1832 for writing the Souvenirs. In chapter 1 of Henry Brulard, three years later, he prepares "to make a thorough examination of conscience." 108 As Brombert (and others) have argued, these are written "not to justify a man, but to discover him," distinguishing his exercise from Catholic, Rousseauesque, and Jacobin confessions. "What counts here is the manner of the exploration, the state of innocence with which Stendhal faces himself, the problematical nature of his approach," Brombert says in comparing Stendhal's texts to Rousseau's Confessions, itself informed by Augustine's. ${ }^{109}$ Mutatis mutandis, they differ as well from the Jacobin "moments of moral self-exposure reminiscent of prerevolutionary Catholic confessions" described by Patrice Higonnet: "They often availed themselves of such occasions [in the National Assemblies and the Clubs] to recount their entire prerevolutionary life, which became

106 Ibid., 450. According to Charton, a bishop (which Julien had once dreamed of becoming) could expect to make ten thousand livres a year in 1842 (Guide, 517). Stendhal himself made eight thousand livres a year as an auditeur du conseil d'Etat (Crouzet, Monsieur moi-même, 118). 107 Crouzet, Monsieur moi-même, 117. 536.

108 Stendhal, Souvenirs d'égotisme, in Oeuvres intimes, 2:430; Stendhal, Vie de Henry Brulard,

109 Brombert, "Introduction," 6. 
in these personalized narratives, the long prologue to the intense, third, and triumphal act of revolutionary drama." 110

Each of Stendhal's autobiographies is a search for a coherent self, a unity of purpose, a definition, an answer to the question, "What kind of man am I?" when the answer is not already clear, or comfortable. ${ }^{111}$ "What have I been? What am I?" "What eye can see itself?" he provocatively asks. ${ }^{112}$ At age fifty, these are the questions that trouble his sleep, as Georges Blin emphasizes: "II do not know myself at all, and it is that which, sometimes, in the night, when I think about it, brings me pain." "113

His answers begin to reassure him. "In 1835," Stendhal writes in Henry Brulard, "I'm discovering the physiognomy of, and the reason for events." He finds the shape and character of himself. "The reader will perhaps think me cruel, but such I was at the age of ten and such I am at fifty-two," he tells himself, and us, when describing his happy reaction to the execution of the king. "From this memory, so present to my gaze, I conclude that in 1793 . . . I was engaged in the pursuit of happiness exactly as I am today; in other, more common terms: my character was absolutely the same as today." The way he loved his mother at age sixshe would die in childbirth when Stendhal was seven-was the way he loved women as an adult, he argued. That as a child he never spoke about what really mattered to him explained his reserve today: "I feel this as keenly in 1835 as I felt it in 1794." Describing his first stay in Paris, he quips, "I adored Saint Simon in 1800 as in 1836. Spinach and Saint Simon have been my only enduring tastes, at least after that of living in Paris on a hundred louis a year, writing books. Félix Faure reminded me in 1829 that I was talking to him in these terms in 1798." ${ }^{114}$ Paths in life are set early, and firmly, in the visual metaphors of Henry Brulard.

Writing from the "desert" of Civitavecchia, ${ }^{115}$ Stendhal is able to find the sublime in the pattern of his life. "Once and for all I give warning to the brave man, the only one perhaps, who has the courage to read me, that all the fine reflections of this sort belong to 1836," he explains while recounting his experience of entering Italy loosely attached to

110 Patrice Higonnet, Goodness beyond Virtue: Jacobins during the French Revolution (Cambridge, MA, 1998), 82.

111 Stendhal, Souvenirs d'égotisme, 429. Stendhal's search for unity resembles that of his characters, all of whom "realize that they can only exploit their genius by becoming something, by discovering some principle of unity within themselves." They need to "become "integrated personalities" (Turnell, "Rouge et le noir," 21).

112 Stendhal, Life of Henry Brulard, $5,8$.

113 Georges Blin, Stendhal et les problèmes de la personnalité (Paris, 1958), 5. Blin is quoting Souvenirs d'égotisme.

114 Stendhal, Life of Henry Brulard, 141, 117, 119, 33, 185, 454.

115 Del Litto, La vie de Stendhal, 279. 
Napoléon's army, being stunned by the beauty of the countryside and the music, and being reborn by it. "I would have been greatly astonished by them in 1800; well versed though I was in Helvétius and Shakespeare, I wouldn't perhaps have understood them." 116

Sloughing off Helvétius, like molting skin, allows him to reexperience the important moments of his life as a process of regeneration. ${ }^{117}$ The self of 1835-36 sees himself "born again" while reading Shakespeare. He "returned to life" when his adolescent infatuation for the actress Mlle Kubly ended. "I am about to be born, as Tristram Shandy says," he explains, as his story takes him to work at the Ministry of War amid the excitement and secrecy of the planning for the battle of Marengo. ${ }^{118}$

Stendhal's recovery of his self allows him to see, as Julien's does, the folly of ambition. "I have never been ambitious," he claims in Henry Brulard, "but in 1811, I thought I was ambitious." The cure for that "true fever of the passions; [that in 1806] he spoke of as ambition" was the discovery of his vocation, his calling. This, memory reveals, happened when he was eleven, while reading a forbidden novel that belonged to his uncle (Félicia ou mes fredaines): "From that moment on, my vocation was settled: to live in Paris writing comedies like Molière." 119

Stendhal's vocation, like Julien's recovery of "self," allows him to "out-narrate" 120 the accidents of postrevolutionary life and give them order and sense. That self is "prior to calculation," fixed and aloof from circumstance. ${ }^{121}$ But whereas Julien's recovery allows him this autonomy, it allows him that and nothing more. It leaves him morally cleansed but with only one option, death. His return to his self encloses him. He finds freedom only in prison, as critics often note for both Julien and Fabrice, the hero of The Charterhouse of Parma. ${ }^{122}$

Vocation is more enabling. Pierre Larousse caught its nineteenthcentury meaning, while disclaiming it, in his Grand dictionnaire universel. Vocation was a word in common use, but real vocations were rare, Larousse warned, and typically directed by fathers, not the self. Mozart

116 Stendhal, Life of Henry Brulard, 477.

117 A summary of evidence about the importance of Helvétius and the Ideologues is in Brombert, Hidden Reader, 164-65. Del Litto describes it in detail throughout Vie intellectuelle de Stendhal, esp. pt. 1 and chap. 1 of pt. 2, 9-294. See also Alciatore, Stendhal et Helvétius.

118 Stendhal, Life of Henry Brulard, 278, 268, 427.

119 Ibid., 17, 185.

120 Rowan Williams, "What Shakes Us," review of "What Is Truth?" Towards a Theological Poetics, by Andrew Shanks, and With the Grain of the Universe: The Church's Witness and Natural Theology, by Stanley Hauerwas, Times Literary Supplement, July 4, 2003, 10.

121 Reddy, Navigation of Feeling, 204. Reddy is summarizing an argument made by Germaine de Staël in De la littérature. noir," 28

122 Crouzet mentions the importance of "la prison heureuse" in "Notice sur Le rouge et le 
is an example of a child whose vocation was prepared for by his father. Mme de Staël is another. "That which is commonly called vocation is in reality just a strategy lit on by the imagination of a child searching for a way to leave his papa and mama, excellent for him. . . . The father cries, the mother weeps." ${ }^{123}$ The child, bored with home and school, finds a way to sanction his independence by invoking his vocation. In the autobiographies presented in Denis Bertholet's Les Français par euxmêmes, 1815-1885, we find vocation used in this familiar sense. Auguste de Vanssay, born in 1785, served seven years as an officer in the Dragoons. Released in 1811, he set off for Saint-Domingue to repair the family fortune: "If I had taken up arms, it was in submission to her [his mother's] will: my vocation called me to another career. I was destined to go to Saint-Domingue." For Etienne-Maurice Deschamps, also born in 1785, vocation took him away from his village in the Franche-Comté to the wars and a filial devotion to Napoléon: "Destiny had spoken: my vocation was totally military." 124

Stendhal implicitly contrasts vocation - "powerful and irresistible," in the words of Sainte-Beuve - to métier. ${ }^{125}$ Pierre Daru, Napoléon's secretary for war and Stendhal's taskmaster, was also a poète de métier, celebrated for his alexandrines, who "approached literature with a bureaucratic mentality." ${ }^{126}$ Stendhal describes his own work as consul in Civitavecchia as a job that pays the bills, his "métier gagne-pain"something that he is very, very good at but that eludes his deeper self. 127

This plunge into the self on the part of Stendhal is the cure for his struggles with ambition, as was Julien's assault on Mme de Rênal. It helps him see his life as guided by something outside will or circumstance. One has only to wish it, to become a genius, he had written to his sister in 1803. But in 1835-36 he is speaking of fate, luck, and destiny: "But chance has guided me by the hand in five or six great circumstances of my life. I really owe Fortune a small statue." 128

Stendhal's vocation also stands in contrast to genius. His Vie de Henry Brulard deplores the allure of genius that led him to waste ten years of his life: "Had I spoken around 1795 of my intention of writing, some man of good sense would have told me: 'Write for two hours a day, genius or no,' a remark that would have led to my making use of ten years of my life fatuously spent waiting for genius." "I always waited

123 Pierre Larousse, Le grand dictionnaire universel (Paris, 1865-90), 24:1141.

124 Quoted in Denis Bertholet, Les Français par eux-mêmes, 1815-1885 (Paris, 1991), 81, 85.

125 Le petit Robert, new ed. (1984), quotes Sainte-Beuve s.v. "vocation."

126 Crouzet, Monsieur moi-même, 67.

127 Stendhal, Vie de Henry Brulard, 958.

128 Stendhal, Life of Henry Brulard, 451. Stendhal often engaged in reflections of this sort after crossing into Italy. 
for the moment of genius," he explained of his young self; "I was only cured of this mania belatedly. . . . Even in 1806, I was waiting for the moment of genius before writing." He could be a great poet, he imagines himself thinking in 1799, if only he could find a "flue for my genius to escape through." 129

Like vocation, genius might enable success, but more intensely, erratically, in a way Stendhal signals as uncongenial to his disciplined self and his desire to achieve. That "quasi-mystical gift that simply occurs, with no help from society," 130 that is romantic genius would obviate the need for ambition by creating its own reason for being, but it is associated from the start of its cultural life with madness and doom with the route $F$ on Stendhal's map of life, perhaps. It is striking that Stendhal's dismissal of genius begins at the very moment when it was being heralded by Mme de Staël (in Corinne or Italy) and Lord Byron (in Childe Harold's Pilgrimage), when romantic genius was finding its niche in postrevolutionary culture. It is even more remarkable because of the affinity between romantic genius and the Stendhalian persona. The exceptional person, who creates brilliant works of art that speak to the future rather than to one's own purblind generations, would seem to describe Stendhal and his address to readers of the future, to the "happy few" who might appreciate his novels. Clearly his argument against genius is one we need to attend.

Stendhal's "calling" helps him come to terms with competition in a more workaday way than genius would, especially his competition with Félix Faure in early Napoleonic France, when "a boundless glory seem[ed] to await all those who would join the great enterprise," a venture into which Stendhal had thrown his lot along with Faure. ${ }^{131}$ Criticism of Faure - "the most worthless of all my friends and the one who has made the largest fortune" - runs throughout his work. Casimir Périer - "a minister, and celebrated, and in my opinion the dupe of Louis-Philippe" - was cast in the same mold. ${ }^{132}$ Faure, in turn, suggested that "if Henri had "remained in the class to which he adhered for some time, if he had followed the path to the Conseil d'Etat, he would be more fair to all those who hold power." 133

But Stendhal did not stay the course that Faure remained on - the route $P$ as sketched in Henry Brulard, the "route of good prefects and

129 Ibid., 203, 391.

130 Andrew Elfenbein, Romantic Genius: The Prehistory of a Homosexual Role (New York, 1999), 5 .

131 Crouzet, Monsieur moi-même, 118.

132 Stendhal, Life of Henry Brulard, 442, 81.

133 Crouzet, Monsieur moi-même, 43. Crouzet is quoting Faure's response to The Charterhouse of Parma. 
members of the Conseil d'Etat," or as labeled in an earlier sketch, the route $C$, the "road to consideration: F. Faure makes himself a peer of France." ${ }^{134}$ Nor did he stay on route $R$, the "path to riches," as described in figure 1. He claimed nonetheless "not to have had such a bad life." "Will the reader believe me if I dare to add that I wouldn't want to change places with Messers. Félix Faure and Mounier, peers of France and once my friends?" 135

Stendhal's cure is effected in part by a recovery of Rousseauesque ideas about the need to listen to one's inner self. This was a recovery on his part but also on the part of postrevolutionary culture overall where we find the translation of Rousseau's ideas into romanticism. La nouvelle Héloïse is a key text for Stendhal as it was for Julien: "Ame sensible, imbued with Rousseau," as del Litto explains. ${ }^{136}$

Critics have argued over the extent to which the appeal of Idéologie for Stendhal overwhelmed the influence of Rousseau. Brombert discusses Stendhal's hopes for a cure for that "'exaltation" of sensibility that came to him in reading Rousseau (and that he hated so much in his moments of genius) - "which according to him has become his 'habitual state' and of which he would like to cure himself." 137 But Stendhal never abandons Rousseau, Brombert shows. As romantic expressivism - the term is Charles Taylor's - becomes an important mood of the new regime, Stendhal's mood fluently turns with it. ${ }^{138}$ To discover one's self is to become that self, as Stendhal's work on his autobiographies expresses it.

Taylor also describes the importance of Rousseau's Profession de foi du vicaire savoyard in secularizing the concept of conscience, or the inner voice that speaks to the truth about oneself. Rousseau's influence, he writes, helps shape a "radical autonomy," definitively modern. "The source of unity and wholeness which Augustine found only in God is now to be found within the self," Taylor claims for the postrevolutionary soul. ${ }^{139}$ Stendhal's grandfather discussed Emile and its "Profession de foi du vicaire savoyard" with him, though Stendhal later declared that he "didn't understand any of it." 140 But that "knowledge of the human

134 Stendhal, Vie de Henry Brulard, 671.

135 Stendhal, Life of Henry Brulard, 67.

136 Del Litto, Vie intellectuelle de Stendhal, 33.

137 Brombert is quoting from Stendhal's Journal, Apr. 1805 (Hidden Reader, 165). "The name of this illness is an 'exaltation of Rousseau'" (ibid., 165).

138 Taylor, Sources of the Self, 368.

139 Ibid., 363, 362. Rousseau, Taylor adds, "is the starting point of a transformation in modern culture towards a deeper inwardness and a radical autonomy" (ibid., 363).

140 Stendhal, Vie de Henry Brulard, 777. However, he did borrow Emile from DuboisFontanelle at the Ecole Centrale in 1796 (ibid., 815). 
heart" was one of life's goals was a lesson his grandfather had always urged on him: "My grandfather constantly dinned into me the grand saying: knowledge of the human heart." 141

The Savoyard curate speaks of the time "when I myself shall suffice for my own happiness." ${ }^{142}$ Stendhal, Brombert argues, "already in [1804] . . . is meditating on the lesson of Rousseau who taught him the right to seek 'happiness' in accordance with one's individual temperament." "The tyranny of derision has diminished nowadays; we owe this to Jean-Jacques. A person can freely say, 'You find pleasure in going to the bois de Boulogne in a carriage and I in going there on foot; he will seem eccentric but not ridiculous.'" 143

Vocation is cast from these notions. It is an inner voice, like the call by God that one might hear in an examination of conscience as witness to the resonance of God's will within our own. From Saint Paul through the Puritans vocation gave meaning to one's life work. "What the late eighteenth century adds is the notion of originality," Taylor explains. "It goes beyond a fixed set of callings to the notion that each human being has some original and unrepeatable 'measure.' We are all called to live up to our originality." 144 The "inner gesture by which God calls a person to whatsoever genre of life, to honor and serve him," as the Dictionnaire de l'Académie française explained in 1694, became "an inner impulse or conviction which tells us of the importance of our own natural fulfillment and of solidarity with our fellow creatures in theirs." 145

Vocation became a practical solution to the ethical crisis posed by capitalism, to those for whom - like Stendhal-self-interest alone and the materialist basis for it seemed inadequate, socialism held no interest, and the aristocratic, nostalgic Catholicism of Chateaubriand was repugnant. Reddy notes that Chateaubriand's "Essai sur les révolutions (1797) and Le génie du christianisme (1802) denounced the self-interest of the new age and glorified the honor and selflessness of the past." 146 But what appeal could Chateaubriand's solution have to the grandson of the enlightened Henri Gagnon, who, Stendhal remembered, often repeated the following exchange at his tutor's expense:

141 Ibid., 761.

142 Quoted in Taylor, Sources of the Self, 362.

143 Quoted in Brombert, Hidden Reader, 173.

144 Taylor, Sources of the Self, 376.

145 Dictionnaire de l’Académie française, 1st ed. (1694), s.v. "vocation," humanities.uchicago .edu/ARTFL.html (Dictionnaires d'autrefois); Taylor, Sources of the Self, 369-70. Taylor is describing the modern conscience.

146 Reddy, Navigation of Feeling, 205. 
"But M[onsieur], why teach this child the Ptolemaic system when you know it to be false?" [his grandfather needled.]

"M[onsieu]r, it explains everything and anyway it is approved by the Church." 147

A kind of subterfuge, perhaps, a belief in vocation allowed for a compromise with liberalism. Competition was more acceptable to some as the unfolding of self-a poetics of self-than as the pursuit of selfinterest. ${ }^{148}$

Can Stendhal's experience be read as representative? Stendhal makes the claim himself, at least with respect to the search for selfmeaning that defines his memoirs: "What consoles me a little for the impertinence of writing so many Is and mes, is that I assume that many very ordinary people in this nineteenth century are doing as I am." 149 Bertholet agrees. The Napoleonic Wars had created "an unprecedented individual . . . a sort of 'new man,' which history may sum up in two words: march, then recount." ${ }^{150}$ Pierre Pachet, in Les baromètres de l'âme, credits Stendhal (along with Maine de Biran and Benjamin Constant) with modernizing the memoir. But is not that mirror of the modern self a reflection of all our selves? ${ }^{151}$

Pachet argues that by applying the Christian practice of the "examination of self," as we have seen Stendhal do, to a soul now understood as existing "without God" or at least "in the absence of grace," we see that self revealed as lone, unstable, shifting with its environment, chameleon-like - perfectly suited, we might add, to the demands of the market economy. ${ }^{152}$ "Our existence is serial and cannot be understood otherwise," as Maine de Biran put it. A self is merely "one unit among the thousands and thousands of beings who are and who were," as Anton Reiser says in the eponymous novel by Karl Moritz. ${ }^{153}$ But does not Stendhal's understanding of vocation offer escape from this "suite" of selves by grounding self-expression in a humanist ethics? 154

147 Stendhal, Life of Henry Brulard, 93.

148 Whitney Walton's work on nineteenth-century women writers suggests that they pursued a similar strategy. By imagining approving fathers, important female writers allowed themselves to work within the patriarchal republican movement ("Republican Women and Republican Families in the Personal Narratives of George Sand, Marie d'Agoult, and Hortense Allart," in Margadant, New Biography, 99-136).

149 Stendhal, Life of Henry Brulard, 197.

150 Bertholet, Les Français par eux-mêmes, 88-89. Bertholet places Stendhal in this group.

151 Pierre Pachet, Les baromètres de l'âme: Naissance du journal intime (Paris, 2001), 125.

152 Ibid., 36-37. Pachet points to both the Christian tradition of self-examination and the influence of the Ideologues on Stendhal's impulse to keep a journal (ibid., 128, 129). It is Stendhal's Journals that interest Pachet, not the autobiographies.

153 Ibid., quoting Maine de Biran (57) and Moritz (37).

154 "Suite" is Moritz's metaphor. See Pachet, Baromètres de l'âme, 37. 
The argument forwarded here of Stendhal as a man at one with his age will not be welcome, perhaps, to those of us in whom Julien's rebellion strikes a welcoming chord. Indeed, the contrast between Stendhal's solution to the problem of ambition and Julien's may be too boldly hailed. Yet the emphasis placed on the ordinary in Stendhal's life may honor the man whose Legion of Honor, he felt, should have been awarded for his day-to-day work as a consul, rather than for his writings. Moreover, what Stendhal created with his life was a plot with as great a contemporary resonance as Julien's story came to have within later European culture. The "master fiction" of Julien Sorel was paralleled by the quieter resolutions of vocation, "in some ways too pervasive to be noticed," as Taylor suggests about "the affirmation of ordinary life" in general in modernizing Europe. ${ }^{155} \mathrm{I}$ hope that this essay speaks also to the "mystery," as Stephen Greenblatt terms it, of the relationship between works and lives - "How is it possible to get from the works to the life and from the life to the works?" 156 - by directing our attention to the thematic relations between lived and invented arguments, between égotisme and the fictions of individualism that its stories tell.

155 Taylor, Sources of the Self, 498. Paul M. Cohen uses the term master fiction in Freedom's Moment: An Essay on the French Idea of Liberty from Rousseau to Foucault (Chicago, 1997), 21.

156 Jonathan Shaw, "The Mysterious Mr. Shakespeare," Harvard Magazine, Sept.-Oct. 2004, 56. Greenblatt refers to the "mystery" he "set out to solve" through writing the biography Will in the World: How Shakespeare Became Shakespeare (New York, 2004). Shaw summarizes Greenblatt's project in the quoted sentence. 